\title{
The Development of Mathematics Curriculum to Increase the Higher Order Thinking Skills in The 21 ${ }^{\text {st }}$ Century Era
}

\author{
Yogi Anggraena ${ }^{1}$, Ishak Abdulhak ${ }^{1}, \operatorname{Rusman}^{1}$ \\ \{yogi_anggraena@yahoo.com, ishak.abdulhak@yahoo.com,rusman_71@yahoo.com\} \\ Department of Curriculum Development, Universitas Pendidikan Indonesia, Bandung, Indonesia ${ }^{1}$
}

\begin{abstract}
This study discusses the development of the mathematics curriculum to increase the higher order thinking skills in the 21-century era. Higher order thinking skills are one of the important competencies in the 21 st century. Higher order thinking skills are defined as thinking skills, reasoning, critical thinking, and problem-solving. Mathematics education has been developing in line with learning theories development, changing of technology, and life demands as well as the using of mathematics within the globalization era in the 21 st century. This research was conducted by a qualitative method with data collection technique through interview and documentation. Interview conducted against the developer of mathematics curriculum, Widyaiswara, Writer textbook of mathematics junior high school. The results show that the government has formulated basic mathematics competence that appeals to the competence of higher order thinking skill, Creating Learning Teacher Module, and Textbook. Teachers are expected to explore further higher order thinking skills.
\end{abstract}

Keywords: Higher order thinking skills, Mathematics, 21 Century.

\section{Introduction}

High-level thinking is one of the most important competencies in the 21 st century and also exactly what students need to do to successfully negotiate the demands of the 21st century [1]. Definitions higher order thinking skills can fall into three categories: (1) those that define higher-order thinking in terms of the transfer, (2) those that define it in terms of critical thinking, and (3) those that define it in terms of problem-solving. Higher-Order Thinking as Transfer is approached as the "top end" of Bloom's (or any other) taxonomy: Analyze, Evaluate, and Create, or, in the older language, Analysis, Synthesis, and Evaluation. Higher-Order Thinking as Critical Thinking, Critical thinking, in the sense of reasonable, reflective thinking focused on deciding what to believe or do. Higher Order Thinking as Problem Solving is the nonautomatic strategizing required for reaching a goal [2].

One of the challenges in the development of a mathematics curriculum in Indonesia is related to Indonesia's participation in the International Trends study in the International Mathematics and Science Study (TIMSS) and the Program for International Student Assessment (PISA). Based on the TIMSS results in 2015 Indonesia's achievements are still not encouraging, Indonesian students are weak in all aspects of content and cognitive for mathematics subjects [3]. Whereas the 2015 PISA results despite the significant increase in Indonesia's achievements, but the overall achievement is still below the OECD average [4]. The most important thing is 
how we conduct follow-up based on diagnoses resulting from the PISA diagnostic survey. Students must be familiarized with high-level thinking skills (HOTS). The measurement of student achievement based on the National Examination turned out to be in line with the achievements of PISA and TIMSS. Students are still weak in high-level thinking skills (such as reasoning/analyzing/evaluating), an everyday class assessment must be familiarized with HOTS questions so that children are motivated by their critical thinking skills [5]. Mathematical learning is too formal, less related to meaning, understanding, and application of mathematical concepts, and fails to provide sufficient attention to reasoning and problem-solving abilities [6].

Based on the above problems, it is necessary to develop a mathematics curriculum that can improve 21 st-century skills so that students' mathematical abilities in Indonesia can be on par with students in other countries, especially OECD countries and able to compete in the 21 stcentury era.

\section{Methods}

The method used in this research is a qualitative method to collect data using interviews and documentation studies techniques. Interviews were conducted on 3 people, they are LA, SW, and ARA. LA is Developers of Mathematics Curriculum, Curriculum and Books Center, Ministry of Education and Culture Curriculum and Book Center (Puskurbuk), Ministry of Education and Culture of the Republic of Indonesia which is the coordinator of the formulation team for Basic and Secondary Mathematics Competencies in Indonesia. SW is Widyaiswara from The Centre for the Development and Empowerment of Educators and Educational Personnel (PPPPTK) Mathematics, Ministry of Education and Culture of the Republic of Indonesia which is the coordinator of the development of Sustainable Professional Development Modules for Mathematics Teachers, especially Junior High School Teachers, and ARA is a Textbooks in Mathematics Writer Coordinator especially whose books are used in all schools in Indonesia that use the 2013 curriculum. The Documentation Studies was carried out by reviewing Basic Competencies, Mathematics Teacher's Sustainable Professional Development Module, and Textbooks of Mathematics, especially Junior High School. Mathematics Basic Competencies are used as a reference by all schools in Indonesia in teaching mathematics material, Mathematics Teacher's Sustainable Professional Development Module is a learning resource for mathematics teachers in improving their competencies so that they are able to take professional responsibilities as well as possible. Textbox in are used by all schools in Indonesia that used the 2013 Curriculum.

\section{Results and Discussion}

\subsection{Curriculum Development in the 21st Century}

Development of 21st Century skills can be done through a curriculum that requires learning to be interdisciplinary, project-based, and research-based. In addition, curriculum content also includes HOTS and technology and multimedia skills (www.p21.org). Higher order thinking skills are defined as thinking skills, reasoning, critical thinking, and problem-solving [2],[7],[8],[9]. HOTS, including the ability to solve problem-solving, critical thinking, creative thinking, reasoning, and decision making. Higher order thinking the ability is one of the important competencies in the modern world, so it must be owned by every learner. 'Difficulty' 
is not the same as higher order thinking. The degree of difficulty in the item not the same as higher order thinking skills. For example, to know the meaning of an uncommon word may have a very high degree of difficulty, but the ability to answer the problem does not include higher order thinking skills. Thus, HOTS issues are not necessarily high-level problems. Higher order thinking skills can be trained in the classroom learning process. Therefore, for learners to have higher thinking skills, then the learning process also provides space for learners to discover the concept of activity-based knowledge. Activity in learning can encourage learners to build creativity and critical thinking. HOTS Problems can be based on real situations in everyday life, where learners are expected to apply the concepts of learning in the classroom to solve the problem. Contextual problems faced by the world community today related to the environment, health, earth and space, and the use of science and technology in various aspects of life. People in the 21 st century live in a technology and media-suffused environment, marked by access to an abundance of information, rapid changes in technology tools, and the ability to collaborate and make individual contributions on an unprecedented scale. To be effective in the 21 st century, citizens and workers must be able to exhibit a range of functional and critical thinking skills related to information, media and technology.

Various study topics related to 21 st-century skills continue to be researched and developed. For example Preparing Teachers for the 21 st Century which contains various studies related to 21st century skills [10], a book entitled Curriculum Models for the 21st Century Using Learning Technologies in Higher Education by Maree Gosper and Dirk Ifenthaler [11], 21st Century Skills [12], and Inquire to 21 Century Learning Ebook [13]. The curriculum model in the 21st century strives to activate innovative learning methods that integrate the use of supporting technology, inquiry-based learning (inquiry-based learning) and problem-solving based problems and higher order thinking skills. In terms of assessment, 21st-century skills and abilities support a balanced assessment, including testing high-quality standards along with effective formative and summative assessment. In more specific contexts, this assessment emphasizes feedback that is useful in student performance that is integrated into everyday learning. Meanwhile, related to the existence and application of technology in assessment, the balance of technology-based assessment, in this case, formative and summative assessment that aims to measure 21st-century skills mastery skills that are dynamic and continuously developing.

\subsection{Development of Mathematics Curriculum to Increase the Higher Order Thinking Skills}

The Study of TIMSS and PISA has become a new standard for mathematics learning. Based on the results of the 2015 TIMMS, in the field of mathematics, Singapore was ranked 1st and Indonesia was ranked 46 of the 60 countries participating in the study [3]. As for PISA Results, Singapura is ranked 1st and Indonesia is ranked 66th out of 72 countries [4], [14]. Research by Lianghuo Fan and Yan Zhu [15] entitled From convergence to divergence: the development of mathematical problem-solving in research, curriculum, and classroom practice in Singapore, needs to be taken into consideration in the development of mathematics learning and assessment in Indonesia. Various study topics related to learning and assessment continue to be researched and developed, including a book by King entitled Higher Order Thinking Skills: Definition, Strategic Teaching, Assessment and a journal entitled Higher Order Thinking in Chemistry Curriculum and its Assessment [16], Standard-based science education and critical thinking [17], What Teacher Knowledge Matters in Effectively Developing Critical Thinkers in the 21st Century Curriculum? [18], and Reasoning-and-proving in the written curriculum: Lessons and meaning for teachers, curriculum designers, and researchers writing [19]. 
Mathematics curriculum standards should emphasize connection as one of the important processes in mathematics instructions. Learning must create students able to recognize and apply math in the context of outside mathematics. This includes creating relationships to the "real world" i.e the world outside the classroom. For that reason, teachers are expected to prepare the real world situation and its context for students in order to make mathematics make sense or acceptable to them. So, students are able to get a chance to recognize and appreciate the relationships between mathematics and their life. Teachers are forced to assist students in creating a more realistic correlation between mathematics and life as making the meaningful mathematics. Even connecting mathematics into real life is not always easy. That is why teachers need abilities to recognize and understand about the mathematical relationships and applications which can be used to develop mathematical instructions. Students establish knowledge through the investigation process by themselves.

In learning mathematics, students are expected to increase their abilities in dealing with reasoning, problem-solving, mathematical communications, mathematical connections, and in using mathematical representations [20], [21], [22], [23], [24], [25]. Mathematics skills and expertise are parts of the life skills which must be owned by the learners especially in the development of reasoning, communication, and problem-solving that facing up by the learners daily. Therefore, the subject of mathematics is necessary to be given to all students started to form the elementary school to provide abilities in logical thinking, analytical, systematical, critical, innovative and creative, and cooperative competencies. These competencies are needed in order students able to gain the ability to gain, managing and using information for the better life in the very much changing situations, uncertain, and very competitive. In doing the learning of mathematics, students can embrace the benefit of learning mathematics.

Table 1. Map of Competencies in Elementary

\begin{tabular}{lll}
\hline Aspects & Elementary School (grade I-III) & $\begin{array}{l}\text { Elementary School } \\
\text { (grade IV-VI) }\end{array}$ \\
\hline Numbers & $\begin{array}{l}\text { Using numbers, simple fractions in } \\
\text { solving daily life problems }\end{array}$ & $\begin{array}{l}\text { Using integers, primes, fractions, } \\
\text { multiples and factors, ranks and simple } \\
\text { roots in solving daily life problems }\end{array}$ \\
$\begin{array}{l}\text { Geometry and } \\
\text { Measurement }\end{array}$ & $\begin{array}{l}\text { Using two-dimensional figure and } \\
\text { simple geometry, the concept of a } \\
\text { unit (weight, length, and time), in two-dimensional figure and simple } \\
\text { solving problems of everyday life } \\
\text { geometry, the relationship between lines, } \\
\text { measurements (weight, length, area, } \\
\text { volume, angle, } \\
\text { Time, velocity, and debit), the location and } \\
\text { coordinates of an object in solving daily } \\
\text { life problems } \\
\text { Collect, present and interpret sole data in } \\
\text { problem-solving everyday life }\end{array}$ \\
\hline $\begin{array}{l}\text { Statistics and } \\
\text { Opportunities }\end{array}$ & $\begin{array}{l}\text { Presents simple single data in image } \\
\text { form }\end{array}$ &
\end{tabular}

In relation to the way of overcoming the situations above, the reformation within curriculum 2013 has constructed the unlimited competency by taxonomy level of a thinking process. It is started from elementary school, junior high school and senior high school, the broader and deepening of knowledge dimensions like factual, conceptual, procedural, metacognitive, and thinking process dimensions such as remembering, understanding, applying, analyzing, evaluating, and creating. In the subject of mathematics, there will be explained into the map of competency (moec, 2015) (can be seen Table 1, Table 2, and Table 3). 
Table 2. Map of Competencies in Junior High School.

\begin{tabular}{|c|c|}
\hline Aspects & Junior High School \\
\hline Numbers & $\begin{array}{l}\text { Using integers, fractional numbers, rank, and roots, number patterns, sequences and } \\
\text { series in the problem-solving daily life }\end{array}$ \\
\hline Algebra & $\begin{array}{l}\text { Using the set, algebraic expressions, relationships and functions, comparisons, social } \\
\text { arithmetic, equations and linear inequalities of one variable, two-linear system of } \\
\text { linear equations, straight-line equations, equations and quadratic functions in solving } \\
\text { problems of everyday life }\end{array}$ \\
\hline $\begin{array}{l}\text { Geometry and } \\
\text { Measurement }\end{array}$ & $\begin{array}{l}\text { Using lines and corners, two-dimensional figure (quadrilateral and triangular), } \\
\text { building flat side space, widening curved sides, circles, congruence and congruence, } \\
\text { and Pythagoras theorem, transforming in the problem solving of daily life }\end{array}$ \\
\hline $\begin{array}{l}\text { Statistics and } \\
\text { Opportunities }\end{array}$ & $\begin{array}{l}\text { Processing, presenting and interpreting data, and using opportunities (empirical and } \\
\text { theoretical) in problem-solving daily life }\end{array}$ \\
\hline
\end{tabular}

An approach is aligned with existing materials in mathematics to develop knowledge, thinking abilities, and skills through direct interactions with learning resources which have been designed in Syllabus and lesson plan. In learning activities, students observe the occasion, event, situation, pattern, phenomenon relate to Mathematics and afterward start to introduce mathematics modeling in several forms; asking or questioning why and how the phenomenon can happen; collecting and digging information through trying, experimenting, reviewing, discussing to deepening the concept that relates to the phenomenon; and associating or analyzing critically in explaining the relationship between concepts and algorithm choosing which appropriate to conceive reasoning, and generalizing, also communicating what have been found in analysis activities.

Table 3. Map of Competencies in Senior High School

\begin{tabular}{lll}
\hline \multicolumn{1}{c}{ Aspects } & \multicolumn{1}{c}{ Senior High School (statutory) } & \multicolumn{1}{c}{ Senior High School (options) } \\
\hline Algebra & Using linear equations and & Using the system of equations and linear and \\
inequalities one variable contains & $\begin{array}{l}\text { quadratic inequalities of two variables, the } \\
\text { absolute values, three-variable }\end{array}$ & system of equations and quadratic inequalities \\
& linear equation, functions, & of two variables, exponential and logarithmic \\
mathematical logic, mathematical & functions, absolute inequalities, fractions, \\
& inductions, two-linear linear & irrational, operations and properties of vectors \\
programming, matrices, sequences & in space, operations on polynomials in \\
and series in the problem solving & problem-solving
\end{tabular}




\begin{tabular}{|c|c|c|}
\hline Aspects & Senior High School (statutory) & Senior High School (options) \\
\hline & $\begin{array}{l}\text { functions in solving daily life } \\
\text { problems }\end{array}$ & \\
\hline Calculus & $\begin{array}{l}\text { Using limit, derivative, and } \\
\text { indefinite integral algebraic } \\
\text { functions in problem-solving }\end{array}$ & $\begin{array}{l}\text { Using the Riemann amount for the area } \\
\text { covered, and the basic theorems of calculus, } \\
\text { integral of course an integral, algebra limits, } \\
\text { trigonometric limits, infinity limits, partial } \\
\text { derivatives, trigonometric derivatives in } \\
\text { problem-solving }\end{array}$ \\
\hline
\end{tabular}

Based on interviews with LA (Developers of Mathematics Curriculum) related to how developers of the mathematics curriculum in order to increase higher order thinking skills in the 21 st century are as follows.

1) The development of the whole mathematics curriculum includes three dimensions, dimensions of subjects, dimensions of competence, and dimensions of context. The dimensions of subjects as the basis used in designing learning by teachers, competency dimensions, including 21 st-century competencies which include higher order thinking skills, another dimension of context, where the usefulness of subjects can be felt in accordance with the real context needed by Indonesian society. Creativity in solving math and creative problems utilizes the skills possessed. Critical thinking must be critical to see the truth of mathematics as a deductive axiomatic system. For example, every step of the work must be rational, there is support for his deduction, why is it acceptable in mathematics. Collaboration. Many things in real life, can no longer work independently, but many demands for cooperation. Maybe if independent cannot be resolved because of the complexity of the problems that exist in the world today, it needs collaboration. Communication, with the demands of the child to be able to communicate mathematically, the results of his work can be a matter of discussion to make deeper understanding, refill material to be studied further, or improve to be more effective and efficient.

2) The way in which the mathematics curriculum developer develops higher order thinking skills in the mathematics curriculum is to formulate basic competencies that require highlevel students' skills in each material. The formulated basic mathematics competencies that require students to cultivate the competence of higher order thinking skills, it can be seen in basic competencies in mathematics at Regulation of the Minister of National Education of the Republic of Indonesia Number 24 the Year 2016 About Primary and Secondary Level core competence and basic competence. In the formulation of the basic competences load operational verb and the range of material, where each material in operational verbs are required to achieve higher order thinking skills.

3) The formulation of basic competencies must still be explained more operationally in the implementation plan of learning.

4) In order for the Teacher to be able to develop learning that can improve higher order thinking skills, the Teacher must be more exploited, not only be reconciled with the existing material and the Teacher also practices related to higher order thinking skills.

Based on the results of interviews with SW (Widyaiswara) related to how the module authors develop a mathematics curriculum in order to increase higher order thinking skills in the 21st-century era are as follows. 
1) The description of the material in the module displays as optimally as possible containing examples of mathematics learning materials for students that have the potential to increase higher order thinking skills

2) Activities of learning activities and Duties / Exercises of participants in the module are arranged in the form of activities that require higher-order thinking participants, as well as

3) Evaluation questions are prepared that demand higher order thinking participants.

4) For the module containing the substance of mathematics (professional), the demands of higher order thinking skills are displayed through examples, questions/cases in explaining the description of the material, the content of learning activities, the content of the task material/training material for learning.

5) For pedagogy-loaded modules, the demands of higher level thinking skills are presented through providing examples of their application to the pedagogy content knowledge, the content of learning activities, the content of task materials/training of learning materials. In order for Teacher to develop lessons that can alert high order thinking skills, the teacher should continue to follow various directives and training on higher-order thinking skills. Before teachers teach with high-level thinking, the teacher must also be able to think high order first by making the setting of learning and questions that demand higher order thinking.

Based on interviews with ARA (Textbooks in Mathematics Writer Coordinator) related to the way the author of a textbook in mathematics developed a mathematics curriculum in order to improve higher order thinking skills in the 21 st century as follows.

1) Awaken students about the need for critical and creative thinking

2) Give examples of questions that contain contradictory information. We can ask them to work in two ways that will produce a contradiction. In that way, we hope they will experience cognitive conflict, and realize the need to be careful in dealing with problems.

3) Give the question that the universe of the variables is still not fixed. For example, specify a graphical image of the equation $x+y=5$. Convince them that the graphics image can vary depending on the universe of the conversation. The graph can only be 4 points if $\mathrm{x}$ and $\mathrm{y}$ are natural numbers, two points if $\mathrm{x}$ and $\mathrm{y}$ are prime numbers, and the line when $\mathrm{x}$ and $\mathrm{y}$ are real numbers. That way, they will be invited to be careful, and always be truth-seeking.

4) Give students open-ended questions. Moreover, questions that are ill-structured and invite students to do it in the form of projects.

5) All materials should contain higher thinking skills. Problems that require higher thinking skills do not always have to be difficult questions. As long as he invites children to analyze, evaluate, and create, it certainly requires higher thinking skills.

6) The teacher must improve higher level skills, namely by learning and learning. Teachers must develop themselves so that they master with the full concept of higher order thinking, the indicator in each learning new concepts, new theorems, and s problem solving, and not tired of doing reflective practices on learning that has been done, as well as conducting research.

Based on the results of the Documentation Study carried out by reviewing Basic Competencies, Mathematics Teacher's Sustainable Professional Development Module, and Textbooks in mathematics, the conclusions are as follows.

1) The scope of the material in Basic Competencies, Mathematics Teachers' Continuous Professional Development Module, and Textbooks in Mathematics are aligned. For elementary and junior high schools, including Numbers, Algebra, Geometry and 
Measurement, and Statistics and Opportunities. For the high school level includes Algebra, Geometry and Measurement, Statistics and Opportunities, Trigonometry, and Calculus. The scope of this material is the same as that taught in other countries.

2) Rough Competency Formulation has demanded higher order thinking skills in each material, but there needs to be a more operational elaboration in a specific guide to be better understood by the teacher.

3) The material of the Mathematics Teachers' Continuous Professional Development Module contains material/examples that are of high-level thinking skills, but the examples still need to be added and developed again.

4) A material of Textbooks in Mathematics contains material/examples that are of higher order thinking skills, but the examples still need to be added and developed again.

\section{Conclusion}

In order for Indonesian students to compete in the 21 st century, especially in the field of mathematics, the students need to get used to solving problems that are higher order thinking skills. It is hoped that with the structuring of competencies that are not limited by the deception of the taxonomy of thinking processes where the breadth and depth of competence of knowledge dimensions for elementary, junior high school levels include: factual, conceptual, procedural, metacognitive and the dimensions of thought processes include: remembering, understanding, applying, analyzing, creating, so that with the formulation of mathematics competence that can develop higher order thinking skills and learning not just memorize the formula, but done by training students 'reasoning and solving problems that relate to daily problems are expected to increase students' ability in reasoning and problem solving in Order to improve the quality of Indonesian students in the 21 st century era. Higher order thinking skills can be trained in classroom learning. Therefore, for learners to have higher thinking skills, then the learning process also provides space for learners to discover the concept of activity-based knowledge. Activity in learning can encourage learners to build creativity and critical thinking. The government has sought to develop higher thinking skills through the formulation of basic competencies, learner module teachers, and textbooks, but the key to success in enhancing higher order thinking skills is a teacher. Teachers are required to continue to learn and explore higher order thinking skills.

\section{References}

[1] A. R. Saavedra, V. D. Opfer, D. Perkins, H. Singmaster, and V. Stewart, "TEACHINGItAND ItLEARNING $\backslash \mathrm{t} 21 \mathrm{ST}$
Lessons 1 tfromltheltLearningltSciences," 2012.

[2] I. Y. Classroom, Assessing Higher-Order Thinking. 2007.

[3] I. V. S. Mullis, M. O. Martin, P. Foy, and A. Arora, "TIMSS 2011 international results in mathematics," 2012.

[4] Organisation for Economic Co-operation and Development, "Country Note : Result from PISA 2015," pp. 1-8, 2016.

[5] M. Forster, "Higher Order," Duke Math. J., vol. 27, pp. 313-318, 1960.

[6] National Council of Teachers of Mathematics (NCTM), "Six Principles for School Mathematics: Executive Summary."

[7] O. G. Duliu, "Electron paramagnetic resonance identification of irradiated cuttlefish 
(Sepia officinalis L.),” Appl. Radiat. Isot., vol. 52, no. 5, pp. 1385-1390, 2000.

[8] T. Dalgleish, J. M. G. . Williams, A.-M. J. Golden, N. Perkins, L. F. Barrett, P. J. Barnard, C. Au Yeung, V. Murphy, R. Elward, K. Tchanturia, and E. Watkins, [ No Title ], vol. 136, no. 1. 2007.

[9] W. F. McComas, Science \& Technology Education Library. 2003.

[10] C. Johnson, Preparing Teachers for the 21st Century. Break the Mold: Teacher Education. 1995.

[11] É. J. Kaszanyitzky, A. Tarpai, S. Jánosi, and et al., Development of an antibiotic resistance monitoring system in Hungary, vol. 50, no. 2. 2002.

[12] B. Trilling and C. Fadel, "21St C Skills."

[13] S. A. Gold, "Not for sale," J Calif Dent Assoc, vol. 33, no. 8, pp. 589-590, 2005.

[14] PISA (Programme for International Student Assessment), "Pisa 2015," pp. 2015-2016, 2015.

[15] L. Fan and Y. Zhu, "From convergence to divergence: The development of mathematical problem solving in research, curriculum, and classroom practice in Singapore," ZDM - Int. J. Math. Educ., vol. 39, no. 5-6, pp. 491-501, 2007.

[16] P. J. Fensham and A. Bellocchi, "Higher order thinking in chemistry curriculum and its assessment," Think. Ski. Creat., vol. 10, pp. 250-264, 2013.

[17] S. A. Forawi, "Standard-based science education and critical thinking," Think. Ski. Creat., vol. 20, pp. 52-62, 2016.

[18] M. A. Ab Kadir, "What Teacher Knowledge Matters in Effectively Developing Critical Thinkers in the 21 st Century Curriculum?," Think. Ski. Creat., vol. 23, pp. 79-90, 2017.

[19] D. R. Thompson, "Reasoning-and-proving in the written curriculum: Lessons and implications for teachers, curriculum designers, and researchers," Int. J. Educ. Res., vol. 64, pp. 141-148, 2014.

[20] M. Isoda, "Lesson study: Problem Solving Approaches in mathematics education as a Japanese experience," Procedia - Soc. Behav. Sci., vol. 8, pp. 17-27, 2010.

[21] J. Anderson, "Mathematics curriculum development and the role of problem solving. In K. School," Aust. Curric. Stud. Assoc. Natl. Bienn. Conf. Curric. A Natl. Conversat., no. May, pp. 1-8, 2009.

[22] L. Fan and Y. Zhu, "Representation of problem-solving procedures: A comparative look at China, Singapore, and US mathematics textbooks," Educ. Stud. Math., vol. 66, no. 1, pp. 61-75, 2007.

[23] J. Hiebert, T. P. Carpenter, E. Fennema, K. Fuson, P. Human, H. Murray, A. Olivier, and D. Wearne, "Problem Solving as a Basis for Reform in Curriculum and Instruction: The Case of Mathematics," Educ. Res., vol. 25, no. 4, pp. 12-21, 1996.

[24] R. E. Mayer, H. Tajika, and C. Stanley, "Mathematical Problem Solving in Japan and the United States: A Controlled Comparison," J. Educ. Psychol., vol. 83, no. 1, pp. 6972, 1991.

[25] B. Y. X. Newton, "Reforms in the U . S .," no. May, pp. 681-685, 2007. 